\title{
Social Justice, Numeracy, and Teaching Statistics at a Community College
}

Edward Volchok

Queensborough Community College/CUNY, evolchok@qcc.cuny.edu

Follow this and additional works at: https://digitalcommons.usf.edu/numeracy

Part of the Business Administration, Management, and Operations Commons, Business Analytics Commons, Business Intelligence Commons, and the Social Statistics Commons

\section{Recommended Citation}

Volchok, Edward. "Social Justice, Numeracy, and Teaching Statistics at a Community College." Numeracy 12, Iss. 1 (2019): Article 6. DOI: https://doi.org/10.5038/1936-4660.12.1.6 


\title{
Social Justice, Numeracy, and Teaching Statistics at a Community College
}

\author{
Abstract \\ The author of this article reflects on the issues of justice, democracy, and numeracy. As one who has \\ taught statistics in a community college for over 12 years, spent 28 years as a Marketing Consultant, and \\ holds a PhD in political science, the author's thesis is that while an advanced, democratic society can only \\ be just with a numerate citizenry, fostering numeracy is not easy. In this article the author describes the \\ daunting tasks of trying to define what justice is and reviews activities from his statistics class that help \\ students develop their numeracy.
}

\section{Keywords}

numeracy, social justice, democracy, statistics, quantitative reasoning, literacy, Teaching Math for Social Justice

\section{Creative Commons License}

$$
\text { (c) (1) (8) }
$$

This work is licensed under a Creative Commons Attribution-Noncommercial 4.0 License

\section{Cover Page Footnote}

Since August 2006, Edward Volchok has taught full-time at Queensborough Community College's Business department teaching statistics as well as marketing research and marketing. For twenty-eight years, the author consulted to Fortune 500 companies on issues relating to marketing communications, marketing research, and customer relationship management. Starting in 1998, the author taught marketing as an adjunct professor at New York University and Stevens Institute of Technology. For several semesters starting in 2004, he taught "Business Math" in the two-year Business program at New York City College of Technology, CUNY's only comprehensive college. 


\section{Introduction}

My belief that fostering quantitative literacy is an important goal for a technologically advanced, democratic, and just society arose in 2006 when I started teaching statistics in the Business department of Queensborough Community College/CUNY. During my second semester at the college, I was appointed to the university's Quantitative Skills Planning Committee. The committee was composed of professors from each of the university's undergraduate colleges; half were mathematicians and half, like me, taught disciplines that required quantitative analysis. While serving on this committee, I read Lynn Arthur Steen's anthology Mathematics and Democracy, which linked numeracy and democracy.

I also talked to mathematicians for the first time since completing my college math requirement. Many of these scholars were content with how mathematics was being taught, but a few were not. I found talking to those who were working to overhaul mathematics instruction reassuring. I had been one of the bored, under-performing students Arnold Packer discussed in his 2001 essay, "What Mathematics Should 'Everyone' Know and Be Able to Do?" I confess, abstract math was difficult for me. My mind wandered in class. I was lost in a fog of "bloodless abstraction" (Packer 2001).

Conversations with my students show that many have experienced the same boredom and frustration with mathematics. They wonder why they should bother. I respond that in graduate school and during my long marketing career, I have come to appreciate the utility quantitative reasoning has in our social, economic, and political lives. I tell students that statistics is not mathematics. Unlike academic mathematics, I say statistics is about making and testing hypotheses about how business and society work. By focusing on practical, real-world examples - those that often deal with social, economic, and political justice - it is easy for me to capture students' attention.

\section{How Numeracy and Justice Are Related}

With the rise of authoritarian populists in many democratic societies, numeracy is more important than ever. A numerate person will understand such economic concerns as payday lending, credit card debt, or servicing student loans. He or she will understand the effect of gerrymandered districts on the kinds of laws enacted and comprehend problems involving health, education, and family life. Thus, numerate citizens are more likely to see through demagogues' lies, and may also be less susceptible to resentments demagogues play upon. A numerate person is more able to participate in economic, social, and political activities and more likely to realize his or her creative, intellectual, economic, and social potential.

Forty years ago, I earned a $\mathrm{PhD}$ in political science. In graduate school, I concentrated on political theory because I felt that statistically inclined political science (behaviorism) can lead to a mechanistic and dehumanized understanding of politics. I was also searching for the meaning of justice. I was fortunate to gain acceptance to the doctoral program at Columbia University, where the senior political theory faculty had studied with Franz Neumann, a leading member of the Frankfurt School. I read the great political thinkers from Plato to Rawls in the context of their historical milieu, and thought about how their teachings might enlighten us today. 
Early in my graduate school education, I read Karl Mannheim's Ideology and Utopia. In this classic work on the sociology of knowledge, Mannheim presents "two slogan-like concepts: "ideology and utopia," both of which emerge from political conflict $(1966,36)$. Ideology reflects the thinking of the ruling or dominant group. Ideology is complexes of ideas designed to maintain the existing order (1966). Utopia, or utopian thinking, is the collection of ideas from those who seek to overturn or transform the existing order. Both ideology and utopia have limitations. Of ideology, Mannheim writes, "ruling groups can in their thinking become so intensively interest-bound to a situation that they are simply no longer able to see certain facts which would undermine their sense of domination" (1966, 36). As for utopian thinking, Mannheim declares that this "wishful representation and the will to action, hides certain aspects of reality" $(1966,36)$. Any movement to increase social justice is, by definition, utopian. Clearly, teaching mathematics for social justice (TMfSJ) is an important example of utopian thinking and, as with any social justice movement, achieving its aims entails a political struggle.

Defining justice is a daunting task. The social and economic theorist Friedrich Hayek is said to have remarked that "whole books and treatises have been written about social justice without offering a definition of it" (Novak 2000). When I read the literature on TMfSJ, I am very sympathetic to the motives of its advocates (Wagner and Stinson 2012; Gutstein and Peterson 2013). I am impressed by their lesson plans, but I am deeply concerned by the lack of rigorous discussion of what social justice is. Social justice demands a more precise definition than that which Justice Potter Stewart famously gave to pornography: "I know it when I see it" (Stewart 1964).

In the concluding essay to Teaching Mathematics for Social Justice: Conversations with Educators, Ubiratan D'Ambrosio takes a step toward defining justice in the context of math education. He asks mathematics educators "to think about a broader conception of social justice, one that aims toward human well-being" (2012, 201). D'Ambrosio adds that "social justice should be understood as an attempt to satisfy the basic needs for a good life: freedom and choice; health and bodily well-being; and social relations anchored in security, peace of mind, and the respect for spiritual experience" $(2012,206)$. I suspect that many readers would nod their heads in agreement with this statement, but the devil is in the details. The TMfSJ community needs an ongoing and rigorous discussion of the meaning of social justice. Reasonable people of goodwill may disagree with what social justice means in general and in the context of teaching mathematics in particular. TMfSJ cannot achieve its aim if social justice lacks a solid philosophical foundation. Yet, few commentators attempt to define social justice with any precision. Today we even see the sad spectacle of hate-filled neo-Nazis attacking a leader of the TMfSJ community (Sol 2018). No doubt everyone involved in the TMfSJ conversation, neo-Nazis included, believes that they are on the side of justice.

When I contemplate the problem of justice, I think of John Rawls' A Theory of Justice. Rawls addresses the question: How can we determine whether a society is just? He contends that justice is fairness. He asks readers to conduct a thought experiment. Imagine a situation - the "original position"-in which we derive fair and impartial principles of justice. In the original position, "no one knows his place in society, his class position or social status; nor does he know his fortune in the distribution of natural assets and abilities, his intelligence and strength, and the like" (Rawls 1972, 137). But we do understand political affairs, economics, social organization, and the "laws" of human psychology 
(Rawls 1972, 137). This is Rawls" "veil of ignorance" that separates a person from his or her particular place in society when the construction of a framework for justice is made.

Under Rawls' veil of ignorance, what sort of society would a reasonable, selfinterested person of goodwill choose? Enlightened self-interest demands that such a person would, according to Rawls, select a system that would benefit the person in society's least desirable circumstances. The rational person, not knowing his or her place, would want a fair, although not necessarily equal, distribution of rights, liberties, powers, opportunities, wealth, and self-respect.

Who would argue that our society is just? Ours is a society where homeless people spend their nights sleeping on sidewalks and their days panhandling, a society in which some of my students lack adequate food and shelter. Who in the original position would think it just for our government to support for-profit colleges that leave students $\$ 50,000$ in debt with no job prospects while it fails to address a backlog of 100,000 fraud complaints against these schools (Flannery 2018)?

Can ideology pierce Rawls' veil of ignorance? Consider Judge George Fitzhugh, an ideologue from antebellum Virginia. With an almost Rawlsian concern for the weak, Fitzhugh argues "slavery protects the weaker members of society just as do the relations of parent, guardian and husband, and is as necessary, as natural, and almost as universal as those relations" (1854). Let us take Fitzhugh at his word. Imagine if he were in Rawls' original position. As a committed racist, Fitzhugh firmly believes the black slave needs the mastery of the white race. As a matter of self-interest, he would select the Southern agrarian slave society even if he was destined to be another man's chattel, toiling from dawn to dusk. Yet what mainstream thinker today would argue that Fitzhugh's racist beau idéal is just?

As an educator, I prefer to think the people behind the veil of ignorance would espouse the views of John Dewey, who wrote, "It is in education more than anywhere else that we have sincerely striven to carry into execution 'the Great American Dream': the vision of a longer and fuller life for the ordinary man, a life of widened freedom, of equal opportunity for each to make of himself all that he is capable of becoming" (1925, 93). Dewey's statement on "popular enlightenment" is probably familiar to many readers of this journal, as Robert Orrill quoted it in his preface to Mathematics and Democracy (2001, xv). As a community college educator, I believe the hallmark of a just, democratic society is open avenues for everyone to obtain the literacies needed for the pursuit of their particular form of happiness. I suspect — indeed, hope — that the readers of this journal would agree. The big question is how do we actually accomplish this?

\section{Numeracy, Justice, and Teaching Statistics at a Community College}

My students reflect the diversity of the borough of Queens. The college is one of the most ethnically diverse in the country. Students trace their ancestry to 127 countries. The college's 2017-18 Fact Book shows that the incoming freshmen of 2017 are 32 percent Hispanic, 25 percent Black, 22 percent Asian, and 15 percent White. Non-resident aliens make up 5 percent of the class. Over 38 percent of freshmen speak a language other than English at home. Of the 78 different languages spoken in these homes, the top five are Spanish, Chinese, Bengali, Korean, and Urdu. Approximately 85 percent of the students graduated from New York City high schools. The average age of all students pursuing an 
associate's degree is 23.3 years old. The average age of freshmen is 19.6 years old. The student body is 53 percent female, although the majority of my business students are male (2017-18 Queensborough Community College Fact Book).

Incoming freshmen take placement tests in reading, writing, and math. Students are weakest in math: 41.75 percent require math remediation compared to 20.50 percent for writing, and 10.10 percent for reading (2017-18 Queensborough Community College Fact Book). By the time students take statistics, they have completed any required math remediation.

The college does not publish information on students' socioeconomic status, but the university does. CUNY has always been a vehicle for New York City's poor to get the education needed for careers that offer upward economic mobility. Nearly a quarter of CUNY undergraduates have household incomes under $\$ 20,000 ; 30.3$ percent work for pay more than 20 hours a week; 53.3 percent are Pell Grant recipients; and 38.1 percent are the first in their family to go to college (Fall 2015 Profile of CUNY Undergraduates).

The college's six-year graduation rate shows that 31.6 percent earn a degree from the college with an additional 8.5 percent graduating from another college (2017-18 Queensborough Community College Fact Book).

Many students arrive at my classroom innumerate. I base this statement on their poor performance on the Quantitative Reasoning for College Science (QuaRCS) Assessment (Follette et al. 2015). Several years ago, two colleagues and I obtained rights to use this assessment. We tested students in my Statistics, Marketing, and Marketing Research classes, several classes taught in the Engineering Technology department, and ninth grade students in the college's Business Technology Early College High School. We observed that most students gave up after attempting a few questions. As a consequence, scores were very low. There was no significant difference between our college students and the ninth graders. We shared our data and our concern that the test was too long with Dr. Katherine B. Follette, the lead developer on the QuaRCS project. Dr. Follette sent us an abridged assessment, which we gave to another group of students. Students still did not complete the assessment. We concluded that students have low numeracy.

\section{Lessons Learned}

Experience shows me that virtually all my students can pass a statistics course and, by extension, can become numerate. This belief is not based on a rigorous assessment with ample statistical power, but on a review of students' work and their expressions of gratitude about how much they learned in my class. Fostering student numeracy is not easy, though, and here I offer some lessons I have learned.

\section{Never Bore Students}

My undergraduate and graduate statistics classes were soporific. Statistics can be boring. You cannot inspire bored students; their minds will drift to more pleasant diversions.

Shortly after earning my doctorate, I had the good fortune to take a class with Professor Ernest Kurnow, who had been teaching statistics at New York University's Graduate School of Business longer than I had been alive. What an inspiration! He was not a drone covered in chalk dust. He was a gadfly whose probing questions awakened our attention and inspired us to improve our understanding. He told interesting and often humorous 
stories that always demonstrated the utilitarian beauty of statistical analysis. Be like Dr. Kurnow.

\section{Expand Students' Minds by Challenging Them}

I want to shake students out of their lethargy. First, I step away from the blackboard; no one can read my handwriting anyway. Instead, I use PowerPoint and a remote presenter so that I can walk away from the podium. I circulate around the classroom as I address questions to students. I draw on examples from the newspaper to show the value of numeracy. These lessons capture students' attention because they relate to the issue of justice. I recently showed them the results of a Gallup poll that reports 53 percent of Republicans favor legalizing marijuana (McCarthy 2018). Students looked at the historical data to see how opinions about marijuana legalization have changed. We used this data to construct confidence intervals and to conduct null hypothesis tests comparing attitudes toward the legalization of marijuana among Republicans, Democrats, and independents. After class, students share with me their views on the legalization of marijuana. A few even complain that the criminal justice system does not treat all marijuana users fairly.

When lecturing on regression, I introduce students to Ockham's Razor, or the law of parsimony. We visit Tyler Vigen's website to explore some rather absurd, spurious correlations (2018). My students love the example showing a 66.6 percent correlation between the number of films Nicolas Cage appeared in and people who drowned in swimming pools. I ask them questions like whether we should expect more people to drown in 2018 when Mr. Cage has appeared in six movies. It is a great way to get students to understand the problems of confounding variables, spurious correlations, and the rigorous methods needed to prove causation.

\section{Have Fun, Play Games}

It is easy to distort the truth with statistics. Charlatans and the inept do this all the time. But you cannot understand our world without the appropriate application of statistics. Throughout the semester, we play a game called "Knave or Fool." There are versions of this game for each lesson. The first game occurs during the second week of class. I use images of charts and tables taken mostly from Fox News. Some are tables or pie charts in which the sum of the relative frequencies exceeds 100 percent. Some are column charts in which the vertical axis does not cross the horizontal axis at zero, or line charts in which the dates on the $\mathrm{x}$-axis are presented as equidistant when they are not. Students discuss why the chart or table is misleading. We then discuss whether the creators of these visuals are knaves who intentionally misrepresent the data, or fools who just do not know better. My students sometimes conclude that knaves are often foolish and that fools occasionally harbor unscrupulous intentions.

I spend a lot of time on measures of central location. I want students to understand the difference between the mean and the median, and why the median often gives a better estimate of what is most typical when the data might be distorted by extremely large or small values. In "Don't Be Fooled: Working Americans Are Worse Off under Trump," a recent opinion piece in the Washington Post, for example, Robert J. Shapiro argues that, when properly measured, earnings for a typical American worker have declined during Trump's presidency (2018). 
To start the game, I read the article to the class. I then tell students that Shapiro was Undersecretary of Commerce for Economic Affairs under President Clinton. The key question: Is Shapiro a knave, fool, or an honest man who presents a credible case? The first two issues students consider are: 1) Does Shapiro have expertise in the question he addresses? 2) Is Shapiro using credible data sources? His source is the Bureau of Labor Statistics, the same source cited by people in the White House who argue that President Trump's economic policies have helped working Americans. We then delve into Shapiro's argument. Shapiro points out that Trump's supporters cite mean earnings for all workers. This is a serious mistake, according to Shapiro: "In times of rising inequality, employees at the top pull up 'average' earnings" (2018). The second issue Shapiro points out is that the figures presented by the White House fail to adjust for inflation. When the median gains in weekly earnings of the American worker were adjusted by the 3.32 percent inflation rate for the 18-month period starting from January 2017, "[weekly earnings] fell by $\$ 16.80$, or 1.9 percent, during Donald Trump's first 18 months as president” (Shapiro 2018). My students concluded that Shapiro is a neither a knave or a fool, but a credible expert. They also learned an important lesson about the mean and the median, as well as how inflation affects the value of the dollar.

Many of my students have problems dealing with percentages. To help them, I invented a foolish friend, Larry Luftmensch. I tell students that Larry is a consultant with only one client. His weekly fee for this client is $\$ 1,000$. But then I tell students that Larry called me in tears when his client slashed his fee by 50 percent. I then inform students that a month later Larry called me and happily told me that his client raised his fee 50 percent. I ask, should Larry be happy? Some students think that the 50 percent raise restores Larry's fees to the level before his 50 percent reduction. Others do the arithmetic. When Larry's $\$ 1,000$ fees were cut in half, his weekly fees dropped to $\$ 500$. Raising his reduced fee by 50 percent brings his weekly fee to $\$ 750$, leaving Larry $\$ 250$ in the hole.

\section{Calculation Skills Are Important, but Do Not Neglect Students' Verbal Skills}

Accurate calculation is a necessary skill. I spend a lot of time taking students step-by-step through the calculation of various techniques. I also show them how quickly they can do these calculations using Microsoft Excel.

To construct an ANOVA table by hand, students could spend a half hour doing simple, repetitive calculations. On my examinations, students must do calculations, but I do not waste their time with repetitive calculations. Instead, I give them a complete ANOVA table and ask them to answer a few basic questions. Questions on linear correlation provide students with a large table of numbers. Students input the appropriate data from this table into the formula for the coefficient of correlation to calculate the $r$ score and then they interpret their findings. They do the same for questions relating to the coefficient of determination and regression.

\section{Give Students a Second Chance at Success}

Statistics is a difficult subject. I expect students to make mistakes. After all, faulty statistical analyses can be found even in peer-reviewed journals. The leading pollsters, I am sure, have extraordinary numeracy. But before every election, I give students a lesson on how top pollsters failed to predict the results of important elections. 
After an exam, sad students frequently appear in my office. I do not want one bad exam to cause them to withdraw from the class because I cannot help students develop their numeracy when they drop the class. I encourage them, answer their questions, tell them where they need to improve, and send them to the college's tutors. I do not offer extra credit assignments, nor do I allow students to retake exams. I do not "dumb down" the curriculum. I encourage persistence. I am delighted by how many students, when given the proper encouragement - even those with GPAs below 2.00- do well on the final exam and show signs of blossoming numeracy.

\section{Conclusion}

There are over 25 statistics books on Amazon with "lies" in the title. Mark Twain's famous remark underscores the link between lying and statistics: "Figures often beguile me, particularly when I have the arranging of them myself; in which case the remark attributed to Disraeli would often apply with justice and force: There are three kinds of lies: lies, damned lies, and statistics" (1907, 471).

Numbers are powerful. Numbers can confound us. They can mislead us. In his book Proofiness, Charles Seife writes, "numbers, figures, and graphs all have the aura of perfection" $(2010,11)$. He also writes, "If you want to get people to believe something really, really stupid, just stick a number on it" $(2010,7)$.

After including numbers in a lie, the second tip from the dictator's handbook is to repeat the lie ad nauseam. "[A]ll effective propaganda must be ... persistently repeated until the very last individual has come to grasp the idea that has been put forward" (Hitler 1939, 148).

Because I strive to develop students' critical thinking skills, I am against propaganda in the classroom and elsewhere, and I certainly oppose indoctrination. It is my hope that helping students develop their numeracy can inoculate them from the "gullibility and cynicism" that leads the masses to "believe everything and nothing" (Arendt 1979, 382). This is a serious problem as evidenced by the toxic mixture of gullibility and cynicism in our society today (Effron 2018).

Many of my students come from impoverished backgrounds. None want to be considered fools. None have shown themselves to be knaves. They come to school hoping that their efforts will lead to a more fulfilling life. They want their fair share of the great American Dream. This is their demand for a more just society.

To avoid the gullibility that corrodes democratic societies, educators must foster students' critical thinking skills. I encourage my students to develop healthy skepticism while avoiding nihilistic cynicism. Justice demands truth, not willful distortions or careless errors. There is nearly universal agreement among educators who seek to improve student numeracy that citizens of a healthy democratic society must be numerate. Yet, international studies consistently show Americans' lackluster performance in math literacy (PISA 2018). Nevertheless, we persist in seeking ways to improve our students' numeracy. This effort is in the interest of justice even though we may often disagree with what justice actually means. Perhaps my thinking is utopian, but I do not believe that innumeracy is compatible with the promise of a just society. 


\section{References}

Arendt, H. 1979. The Origins of Totalitarianism. New York, NY: Harcourt Brace \& Co.

D’Ambrosio, U. 2012. "A Broad Concept of Social Justice.” In Teaching Mathematics for Social Justice: A Conversation with Educators. Wager, A. A. and D. W. Stinson, eds. Reston, VA: The National Council of Teaching Mathematics, Inc.

Dewey, J. 1925. “Culture and Human Nature.” In The Later Works of John Dewey, Vol. 13. JoAnn Boydston, ed. Carbondale, IL: Southern Illinois University Press, 1988.

Effron, D. A. 2018. "Why Trump Supporters Don't Mind His Lies." The New York Times. April 28. https://www.nytimes.com/2018/04/28/opinion/sunday/why-trumpsupporters-dont-mind-his-lies.html.

"Fall 2015 Profile of CUNY Undergraduates." 2016. http://www2.cuny.edu/wpcontent/uploads/sites/4/media-assets/ug_student_profile_f15.pdf.

Fitzhugh, G.1854. Sociology for the South, or the Failure of Free Society. Richmond, VA: A. Morris Publisher. Excerpts found at: http://stage.centerforthehumanities.org/sites/default/files/media/Slavery\%20Justified. pdf.

Flannery, M. E. 2018. "Despite Widespread Fraud, For-Profit Colleges Get Green Light from DeVos." NEAToday. June 1. http://neatoday.org/2018/06/01/for-profitcolleges-fraud/.

Follette, K. B., D. W. McCarthy, E. Dokter, S. Buxner, E. Prather. 2015. The Quantitative Reasoning for College Science (QuaRCS) Assessment, 1: Development and Evaluation. Numeracy 8(2): Article 2. https://doi.org/10.5038/1936-4660.8.2.2.

Gutstein, E. and Bob Peterson, eds. 2013. Rethinking Mathematics: Teaching Social Justice by the Numbers. Milwaukee, WI: A Rethinking Schools Publication.

Hitler, A. 1939 Mein Kampf. Translated by James Murphy. London, UK: Hurst and Blackett Ltd. https://mk.christogenea.org/_files/Adolf\%20Hitler\%20\%20Mein\%20Kampf\%20english\%20translation\%20unexpurgated\%201939.pdf.

Mannheim, K. 1966. Ideology and Utopia: An Introduction to the Sociology of Knowledge. New York, NY: Harcourt Brace \& World, Inc.

McCarthy, J. 2018. "Two in Three Americans Now Support Legalizing Marijuana." Gallup. October 22. https://news.gallup.com/poll/243908/two-three-americanssupport-legalizingmarijuana.aspx?g_source=link_NEWSV9\&g_medium=TOPIC\&g_campaign=item \&g_content=Two \%2520in\%2520Three\%2520Americans\%2520Now\%2520Support \%2520Legalizing\%2520Marijuana.

Novak, M. 2000. "Defining Social Justice.” First Things. December. https://www.firstthings.com/article/2000/12/defining-social-justice.

Orrill, R. 2001. "Mathematics, Numeracy, and Democracy." In Mathematics and Democracy: The Case for Quantitative Literacy. Steen, L. A., ed. Princeton: The Woodrow Wilson National Fellowship Foundation.

Packer, A. 2001. "What Mathematics Should 'Everyone' Be Able to Do?” Paper prepared for National Forum on Quantitative Literacy. http://www.gram.edu/sacs/qep/chapter\%205/5 19PackeraWhatMath.pdf.

PISA. 2018. "PISA 2015: Results in Focus.” https://www.oecd.org/pisa/pisa-2015results-in-focus.pdf. 
Rawls, J. 1971. A Theory of Justice. Cambridge, MA: The Belknap Press of Harvard University.

Seife, C. 2010. Proofiness: The Dark Arts of Mathematical Deception. New York: Viking.

Shapiro, R. J. 2018. "Don't Be Fooled: Working Americans Are Worse Off under Trump." The Washington Post. September 30.

https://www.washingtonpost.com/opinions/dont-be-fooled-working-americans-areworse-off-under-trump/2018/09/30/f789f198-be82-11e8-be7052bd11fe18af_story.html?utm term=.d616d53e375a.

Sol, A. 'Kike Math Teacher Promotes 'Social Justice Mathematics' to Brainwash Kids into Communism." The Daily Stormer. 2018. https://dailystormer.name/kike-mathteacher-promotes-social-justice-mathematics-to-brainwash-kids-into-communism/.

Steen, L. A., ed. 2001. Mathematics and Democracy: The Case for Quantitative Literacy. Princeton: The Woodrow Wilson National Fellowship Foundation.

Stewart, P. 1964. Jacobellis v. Ohio, 378 U.S. 184 (Stewart, J. Concurring). https://supreme.justia.com/cases/federal/us/378/184/.

Twain, M. 2016. The Project Gutenberg EBook of Chapters from My Autobiography. Chapter 20. http://www.gutenberg.org/files/19987/19987-h/19987-h.htm

Vigen, Tyler. 2018. Spurious Correlations. Tylervigen.com. http://www.tylervigen.com/spurious-correlations.

Wagner, A. A. and D. W. Stinston, eds. 2012. Teaching Mathematics for Social Justice: Conversations with Educators. Reston, VA: The National Association of Teachers of Mathematics, Inc.

“2017-18 Queensborough Community College Fact Book.” 2018. http://www.qcc.cuny.edu/oira/docs/Factbook-2018.pdf. 